\title{
Composition and diversity of the Chironomidae in subtropical streams: effects of environmental predictors and temporal analysis
}

\author{
Composição e diversidade de Chironomidae em riachos Subtropicais: \\ efeitos de preditores ambientais e análise temporal
}

Rozane Maria Restello ${ }^{1,3}$, Cristiane Biasi ${ }^{2}$, Pedro Felipe Moutinho Bernardo de Moraes ${ }^{3}$, Gabriella Gabriel ${ }^{3}$ and Luiz Ubiratan Hepp ${ }^{1,3}$

${ }^{1}$ Programa de Pós-graduação em Ecologia, Departamento de Ciências Biológicas, Universidade Regional Integrada do Alto Uruguai e das Missôes, Campus de Erechim, Av. Sete de Setembro, 1621, CEP 99700-000, Erechim, RS, Brazil

e-mail: rrozane@uricer.edu.br; luizuhepp@gmail.com

${ }^{2}$ Programa de Pós-graduação em Biodiversidade Animal, Departamento de Biologia, Centro de Ciências Naturais e Exatas, Universidade Federal de Santa Maria - UFSM, Faixa de Camobi, Km 09, prédio 17, sala 1140, CEP 97105-900, Santa Maria, RS, Brazil e-mail: cristiane.biasi@gmail.com

${ }^{3}$ Laboratório de Biomonitoramento, Departamento de Ciências Biológicas, Universidade Regional Integrada do Alto Uruguai e das Missões, Campus de Erechim, Av. Sete de Setembro, 1621, CEP 99700-000, Erechim, RS, Brazil e-mail: gabriella_gabriel@ymailcom; pedro.fmb.moraes@gmail.com.

\begin{abstract}
Aims: The aims of this study were (i) to evaluate the spatial and temporal distribution of chironomids in subtropical streams and (ii) to investigate the importance of environmental predictors in the distribution of this group. Methods: Samples were collected in four annual seasons between 2010 and 2011, in 10 streams located in an agricultural matrix in southern Brazil, using a Surber sampler. Organisms were identified to the genus level. Some environmental variables were analysed in the sampling sites of the Chironomidae. The variations in abundance and diversity were compared by Analysis of Variance, whereas the community composition was analysed using Multivariate Analysis of Variance. A Redundance Analysis was used to evaluate the effect of environmental variables on the chironomid community. Results: 7,349 individuals were identified, belonging to three subfamilies (Chironominae, Tanypodinae and Orthocladiinae) and 57 genera. The abundance and richness of the Chironomidae were similar between sites and seasons. However, the composition varied spatially and temporally $(p<0.001)$. Water temperature, total organic carbon, total nitrogen and carbon:nitrogen ratio were variables that influenced the chironomid community. The genera Thienemanniela, Pentaneura, Paratanytarsus, Parapentaneura, Parametriocnemus, Hudsonimyia, Labrundinea and Larsia were present in summer, whereas Parakiefferiella, Paramerina, Metriocnemus were indicators for winter. Conclusions: The spatial distribution of chironomids was directly related to the environmental conditions of the sampling sites. The temporal variation in the community followed a pattern in relation to water temperature. The variables physical and chemical operate as environmental filters and thereby alter the chironomid community.
\end{abstract}

Keywords: aquatic insects, environmental filters, physicochemical variables, temporal variation.

Resumo: Objetivos: o objetivo deste estudo foi avaliar a distribuiçâo espacial e temporal dos Chironomidae em riachos subtropicais e investigar a importância dos preditores ambientais na distribuição deste grupo. Métodos: As coletas foram realizadas nas quatro estações anuais entre 2010 e 2011, em dez riachos localizados em matriz agrícola no sul do Brasil, utilizando um amostrador Surber. Os organismos foram identificados até nível de gênero. Algumas variáveis ambientais foram analisadas nos locais de coleta dos Chironomidae. As variaçôes entre abundância e riqueza foram comparadas por meio de uma ANOVA, enquanto que a composição da comunidade foi analisada por meio de uma MANOVA. Uma RDA foi utilizada para avaliar o efeito das variáveis ambientais sobre a comunidade de Chironomidae. Resultados: foram identificados 7,349 indivíduos pertencentes a três subfamílias (Chironominae, Tanypodinae e Orthocladiinae) e 57 gêneros. A abundância e riqueza de Chironomidae foram similares entre os locais e 
estações do ano. No entanto, a composição variou espacial e temporalmente $(\mathrm{p}<0.001)$. Temperatura da água, carbono orgânico total, nitrogênio total e relação carbono:nitrogênio foram as variáveis que influenciaram a comunidade de Chironomidae. Houve a indicação dos gêneros Thienemanniela, Pentaneura, Paratanytarsus, Parapentaneura, Parametriocnemus, Hudsonimyia, Labrundinea e Larsia para o verão, enquanto que: Parakiefferiella, Paramerina, Metriocnemus foram indicadores para a estação do inverno. Conclusóes: a distribuiçâo espacial dos Chironomidae esteve diretamente relacionada com as condiçóes ambientais dos locais. A variação temporal observada na comunidade seguiu um padrão em relação à temperatura da água. As variáveis físicas e químicas avaliadas podem estar operando como filtros ambientais e com isso alteram a comunidade de Chironomidae.

Palavras-chave: insetos aquáticos, filtros ambientais, variáveis físicas e químicas, variação temporal.

\section{Introduction}

Biological communities are structured based on interactions between species, with abiotic and biotic factors at different spatial and temporal scales (Peeters et al., 2004; Anjos et al., 2011). Variations in the composition of aquatic communities at small scales are usually explained by physicochemical variables of water quality, which combined with spatial data, contribute to explain the biological diversity and relationships of aquatic organisms with the environment (Hepp and Melo, 2013). Factors such as morphological characteristics of the environment (Silver et al., 2004; Chaib et al., 2013), substrate type (Hepp et al., 2012; König and Santos, 2013), water quality (Calle-Martínez and Casas, 2006; Tejerina and Malizia, 2012; Chaib et al., 2013), and availability of food resources (Peeters et al., 2004) are common variables that can affect the richness and diversity of aquatic invertebrates (Fesl, 2002). Moreover, anthropogenic disturbances in the environment as riparian vegetation removal and land use can affect the natural conditions of ecosystems and alter the structure of different communities, such as those of chironomids (Sensolo et al., 2012; König and Santos, 2013).

The Chironomidae is the most abundant and diverse group of macroinvertebrates in aquatic ecosystems, with 4147 described spcies in the world and 618 in Neotrpical region (Ferrington, 2008). In Brazil, 320 species have been described in limnic ecosystems, however, this number is underestimated, as studies on the biology, taxonomy and ecology of the Chironomidae in the country are scarce (Mendes and Pinho, 2006). Chironomidae family members confer ecological significance in the ecological and energy partition of resources in the environment, making them important in the biotic stability of aquatic ecosystems (Ferrington, 2008). The success of this group in different environments occur because physiological adaptations into inhabit differents places with unstable environmental variables (Entrekin et al., 2007). The Chironomidae possesses a greater fisiological ability to tolerate various environments than other groups of aquatic insects, since environmental variables such as altitude, water temperature, conductivity, and $\mathrm{pH}$ influence their temporal distribution (Tejerina and Malizia, 2012) and are excellent indicators of environmental conditions (Brodersen and Anderson, 2002).

The effect of seasonal patterns on the composition of chironomids can also be tested, as different climatic conditions might favour the emergence of species (García and Suárez, 2007). However, this might be a consequence of natural variability within the community and often be confused with decreases due to environmental disturbance (Milošević et al., 2012). Changes in rainfall promote common disorders in streams (Tejerina and Malizia, 2012). One of the main effects of spates is the removal of organic matter organic matter adhered to substrates and consequently to hinder the colonisation of invertebrates (Rosin and Takeda, 2007).

The effects of environmental conditions variation on aquatic communities can be clearly observed in chironomids, depending on the wide distribution that this group can achieve (Tokeshi, 1995; Takeda et al., 2004). Changes in the composition and structure of the chironomid community can elucidate the consequences of anthropogenic activities or the natural deterioration of stream ecosystems (Armitage et al., 1995).

Anthropogenic impacts are commonly observed in southern Brazil, mainly due to the replacement of forested areas for cropland and pasture (Hepp et al., 2010). The attributes of the landscape on a large scale can be transferred to particular responses on a smaller scale, promoting for instance changes in environmental parameters such as temperature and 
nutrient input that shape the parameters of aquatic biodiversity (Sensolo et al., 2012). These parameters can act as environmental filters, selecting species that occur at a given site due to limiting environmental conditions (Roque et al., 2010). Thus, only species that have attributes that give them the ability to get through such conditions will be able to survive in a particular location.

Knowledge concerning to the patterns of the chironomid community is essential to construct a database useful for biomonitoring programmes (Milošević et al., 2012). Few studies report the spatial and temporal distribution of this group in the subtropical region, mainly due to the difficulty in identifying larvae at the genus and species levels, and also due to their great taxonomic variability (Raunio et al., 2011). Thus, this study aims to (i) evaluate the spatial and temporal distribution of chironomids in subtropical streams, (ii) investigate the importance of environmental predictors in the distribution of this group, and (iii) contribute to the knowledge of the biodiversity of the group in subtropical streams. Our hypotheses are that the variability of chironomid community follows a gradient in relation to environmental predictors, including temperature and nutrients that act as environmental filters that favour the dominant groups, and that temporal variations exist in the composition of the community, especially among the summer and winter communitites (intraannual), due to variation in rainfall between these seasons.

\section{Material and Methods}

\subsection{Study area}

We conducted this study in 10 streams of $1^{\text {st }}$ to $3^{\text {rd }}$ order in the upper Uruguay River Basin (between $27^{\circ} 12^{\prime} 59^{\prime \prime}$ and $28^{\circ} 00^{\prime} 47^{\prime \prime} S$; and $52^{\circ} 48^{\prime} 12^{\prime \prime}$ and 51.49'34"W (Faxinalzinho $\mathrm{N}=2$, Marcelino Ramos $\mathrm{N}=2$, Três arroios $\mathrm{N}=2$ and Erechim $\mathrm{N}=4$; Figure 1). The region has an altitude ranging from 400-800 m (Butzke, 1997), mean annual temperature is $17.6^{\circ} \mathrm{C}$, and rainfall annual mean of $1,912.3 \mathrm{~mm}$ (Bernardi and Budke, 2010). These elements characterise the climate of the area as belonging to the Köppen category Cfb (Moreno, 1961; Bernardi and Budke, 2010). The geology and soils consist of a basalt formation, and the soil is classified as "EC" (Oxisol Roxodistrófico). The vegetation is characterised by a mixed vegetation of Araucaria Forest and Subtropical Atlantic Forest (Oliveira-Filho et al., 2013). The region has an economy based on agriculture (soy, corn, wheat), which reflects about $70 \%$ of the landscape with anthropogenic uses. All studied streams are located in an agricultural matrix and have different percentages of vegetation in their riparian zone

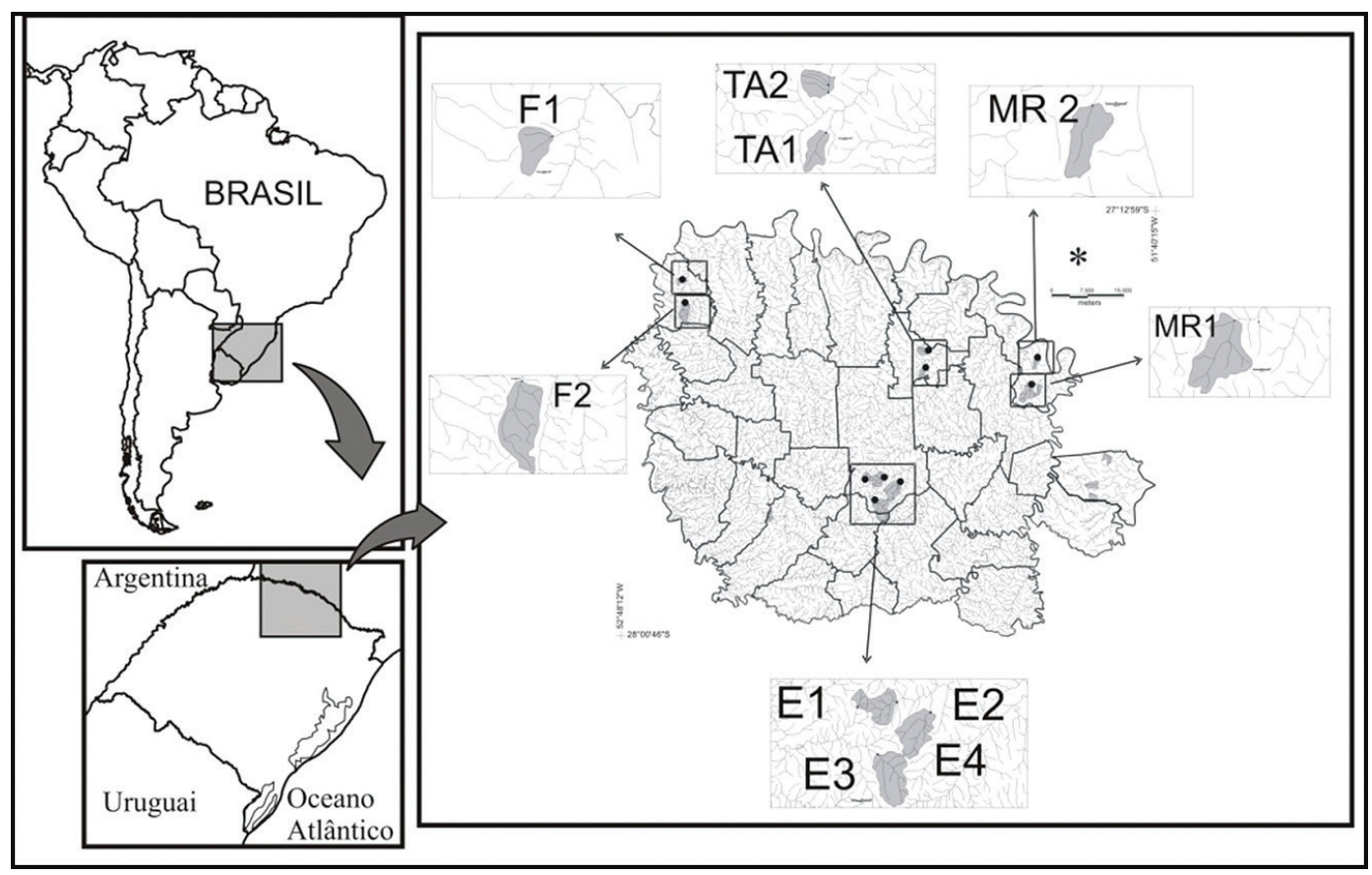

Figure 1. Location of the sampling sites in the Alto Uruguai region, $\mathrm{F}$ (Faxinalzinho, $\mathrm{N}=2$ ), TA (Três Arroios, $\mathrm{N}=2$ ), MR (Marcelino Ramos, N=2), E (Erechim, N=4), Rio Grande do Sul, Brazil. 
(ranging from 6\% to 26\%) (Decian et al., 2009; Sensolo et al., 2012).

\subsection{Chironomidae collection}

Chironomid larvae were collected in each stream at the different seasons of the year (spring, summer, autumn and winter) during 2010 and 2011. Three sub-samples were taken by working the Surber's metal frame (with an area $0.09 \mathrm{~m}^{2}$ and net with mesh size of $250 \mu \mathrm{m}$ ) into the rocky stream bottom. The material was fixed in the field with $80 \%$ ethanol, placed in plastic vials and taken to the laboratory for separation of the individuals of the family Chironomidae from the other groups. The bleaching solution for larval identification consisted of $10 \%$ potassium hydroxide and was applied for $24 \mathrm{~h}$. After creating semipermanent slides with Hoyer's solution, individuals were analysed with an optical microscope at a magnification of $1,000 \times$. Identification was performed to the genus level using the identification key of Epler (2001) and Trivinho-Strixino (2011). The organisms identified were listed and deposited in the Collection of Benthic Invertebrates of the Regional Museum of the Upper Uruguay (MuRAU/URI - Erechim).

\subsection{Water quality variables}

Environmental variables ( $\mathrm{pH}$, dissolved oxygen, conductivity, turbidity, total dissolved solids, and water temperature) were analysed with a Horiba ${ }^{\oplus}$ U50 multiparameter analyser. Water samples were collected for quantification of the levels of total organic carbon (TOC) and total nitrogen (TN). These analyses were performed using a Determinator Organic Carbon TOC-VCSH (Shimadzu ${ }^{\oplus}$. The methods for the analysis of these parameters are described in APHA (1998).

\subsection{Data analysis}

The abundance and richness of organisms were estimated in each sample. To evaluate differences in abundance and richness of the Chironomidae genera between the sampling sites and seasons, an analysis of variance (one-way ANOVA) was performed. To evaluate differences in Chironomidae genera composition between the sampling localities and annual seasons a multivariate analysis of variance (MANOVA) was carried out. To identify indicator genera for different periods of the year and sampling sites, we used the indicator species analysis method proposed by Dufrêne and Legendre (1997). To evaluate the influence of environmental variables on the distribution of organisms, we performed a redundancy analysis (RDA) using an array of biological abundance data transformed by $\log (x+1)$. The second array used in RDA comprised environmental data. Analyses were conducted using the "vegan" package (Oksanen et al., 2012) in R software (R Foundation for Statistical Computing, 2010).

\section{Results}

We identified 7,349 organisms in all study sites, distributed into three subfamilies (Chironominae, Tanypodinae, and Orthocladiinae) and 57 genera (Table 1). The Chironominae showed the greatest abundance, representing $49 \%$ of the total and 23 genera. The Orthocladiinae represented $39 \%$ of the total sample and was represented by 11 genera. The Tanypodinae represented $12 \%$ of the total and 11 genera. The most abundant genera during the study were Polypedilum (20\% of the total) and Rheotanytarsus (19\% of the total). The abundance and richness of the Chironomidae were similar spatially and temporally ( $p>0.05$; Figure 2$)$.

We found spatial and temporal variations in the composition of chironomid communities. Among the sites, the most striking differences were between Erechim streams in relation to the others (MANOVA: $\mathrm{F}_{3,64}=3.303, p=0.001$ ). Differences between the seasons in terms of temperature became clear (summer and winter; $\mathrm{F}_{3,64}=3.009$, $p=0.001)$. Intermediate seasons showed a similar composition to each other, and the similarity between the following seasons (e.g., spring with summer and autumn with winter). The indicator species analysis revealed indicator taxa for summer: Thienemanniela, Pentaneura, Paratanytarsus, Parapentaneura, Parametriocnemus, Hudsonimyia, Labrundinea and Larsia, whereas Parakiefferiella, Paramerina, Metriocnemus showed potential as winter indicator genera.

The distribution of organisms was related to water temperature, and to eutrophication indicator variables (TOC, $\mathrm{TN}$, and $\mathrm{C}: \mathrm{N}$ ratio; Table 2; Figure 3). However, in the RDA analysis, the most abundant genera were negatively influenced by TOC variables, $\mathrm{TN}$, and the $\mathrm{C}: \mathrm{N}$ ratio, indicating some sensitivity of the most abundant genera (Figure 3). The higher water temperature-related collections were made in the summer and spring, whereas the streams of Marcelino Ramos and Três Arroios had a higher concentration of TN and a higher $\mathrm{C}: \mathrm{N}$ ratio. 


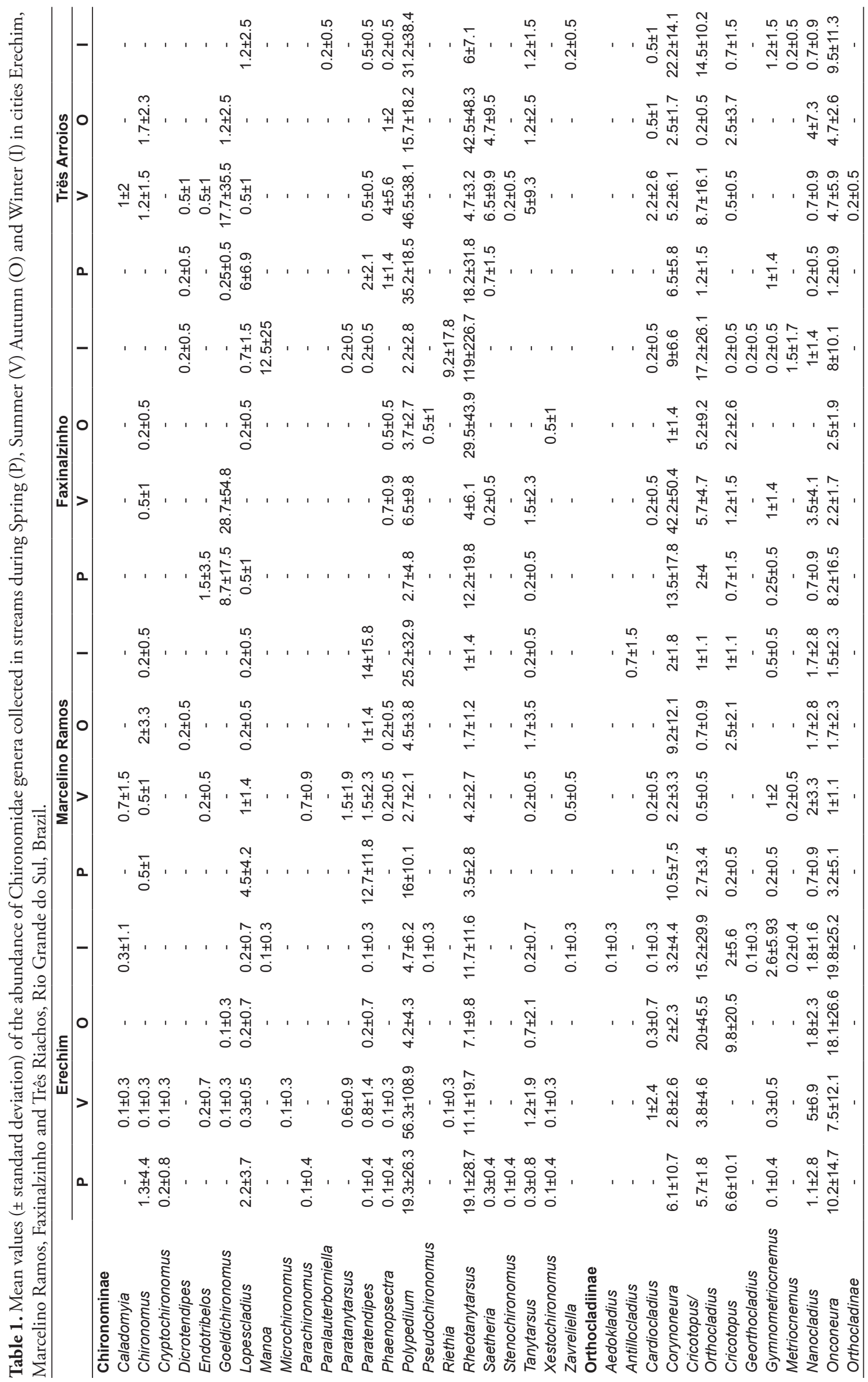




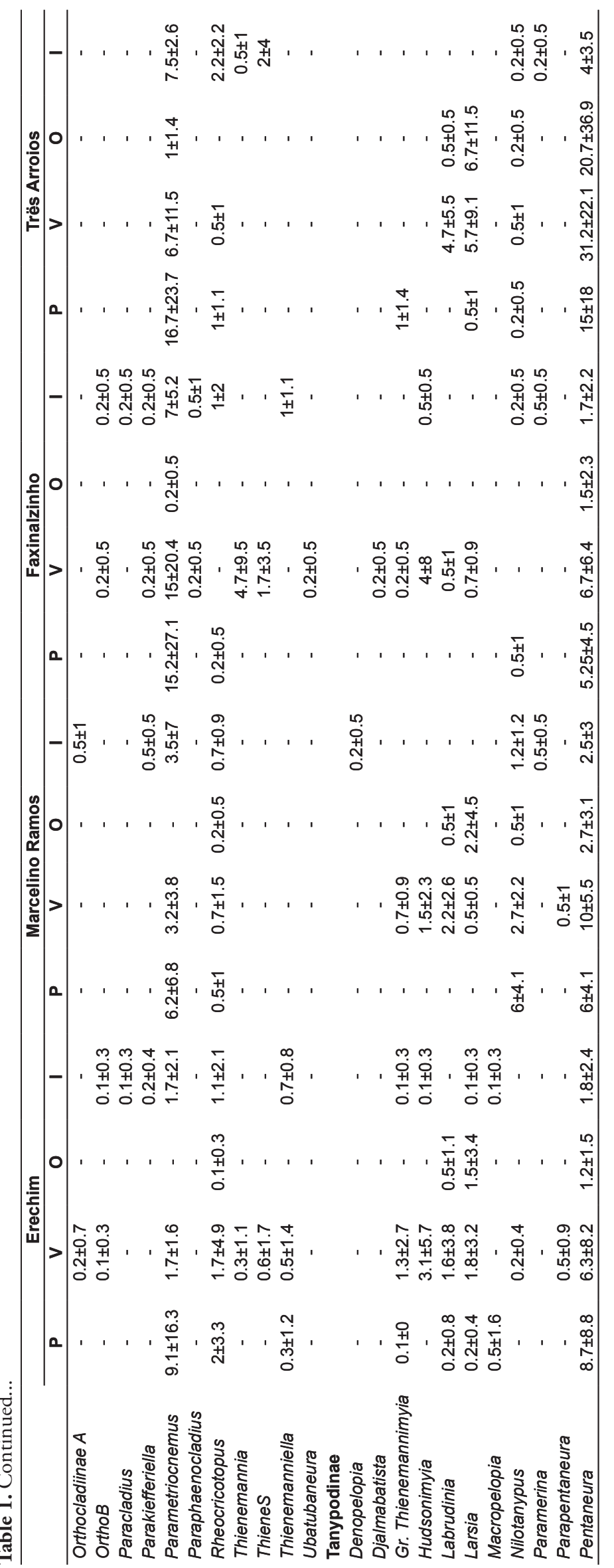



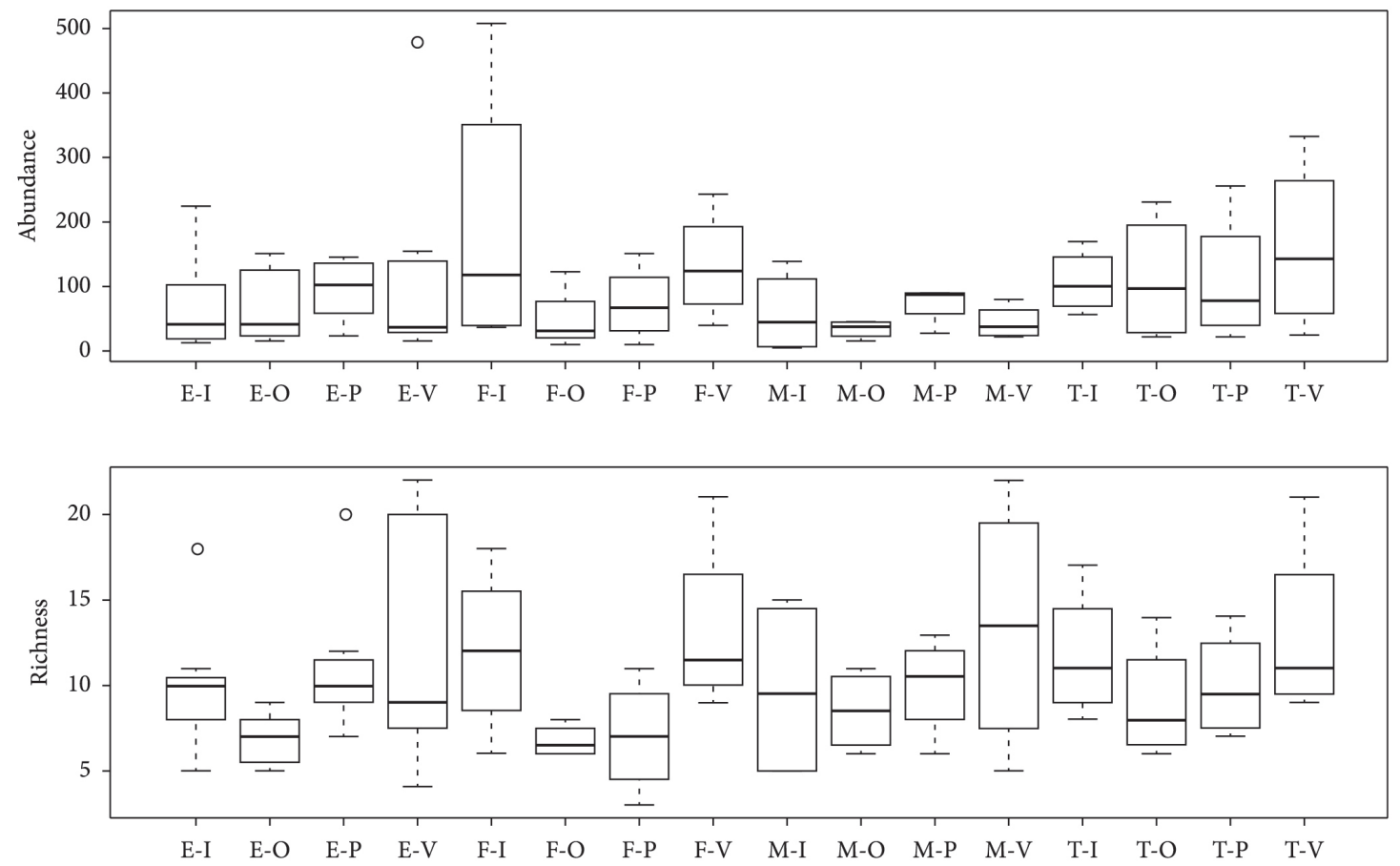

Figure 2. Abundance and richeness of the Chironomidae genera in the streams in Alto Uruguai region, Rio Grande do Sul, Brazil. E: Erechim, F: Faxinalzinho. M: Marcelino Ramos, T: Três Arroios. I: winter, P: Spring, V: Summer, O: Autum

\section{Discussion}

The Chironomidae is a heterogeneous, diverse and important family for structuring aquatic communities (Pinder, 1986; Armitage et al., 1995; Merritt et al., 2008; Ferrington, 2008). In our study, we found two-fold more genera (57 genera) than other studies conducted in streams in the subtropical region (29 genera recorded by Sensolo et al., 2012; 20 genera by Battistoni et al., 2013; 29 genera by König and Santos, 2013). For tropical streams, Aburaya and Callil (2007) identified 27 genera. Fesl (2002) studied streams in temperate regions and found 43 genera distributed among five subfamilies. Calle-Martínez and Casas (2006) also found 23 genera (three subfamilies) in temperate streams. We sampled three subfamilies in our study and observed a great amount of genera compared with other studies, both in tropic and temperate regions.

Polypedilum and Rheotanytarsus together accounted for approximately $40 \%$ of the total organisms, revealing their importance in structuring the community. Polypedilum is often indicated as tolerant to pollutants, such as diffuse contamination arising from agricultural activities (Macdonald and Taylor, 2006). This genus is cosmopolitan, comprising species with multiple dietary habits
(Merritt et al., 2008), including tolerant to a broad range of environmental conditions species (Silva et al., 2013). Polypedilum immatures are easily found in many types of substrates and sediments and have great adaptability (Serpa-Filho et al., 2007). Rheotanytarsus is a filltering-collector and is abundant among other genera of the Chironomidae (Gonçalves Junior et al., 2003; Biasi et al., 2013; König and Santos, 2013). Rheotanytarsus larvae can also tolerate a wide range of environmental disturbances such as nutrient enrichment, a factor that is common in aquatic environments with an agricultural influence, as Polypedilum (Roque et al., 2000; Gresens et al., 2007), as in this study.

Our results indicate that variations in the Chironomidae community depend on seasonal and spatial factors. Approximately $50 \%$ of the variation in the composition of the the Chironomidae community can be explained by physico-chemical variables. The streams studied had an environmental gradient, particularly in the concentrations of TOC, TN, and the C:N ratio. This effect on the community in local scale might be driven by large-scale spatial factors, such as landscape attributes. This is probably because agricultural activities (predominantly in the vicinity of streams) contribute to the diffuse pollution of water bodies 


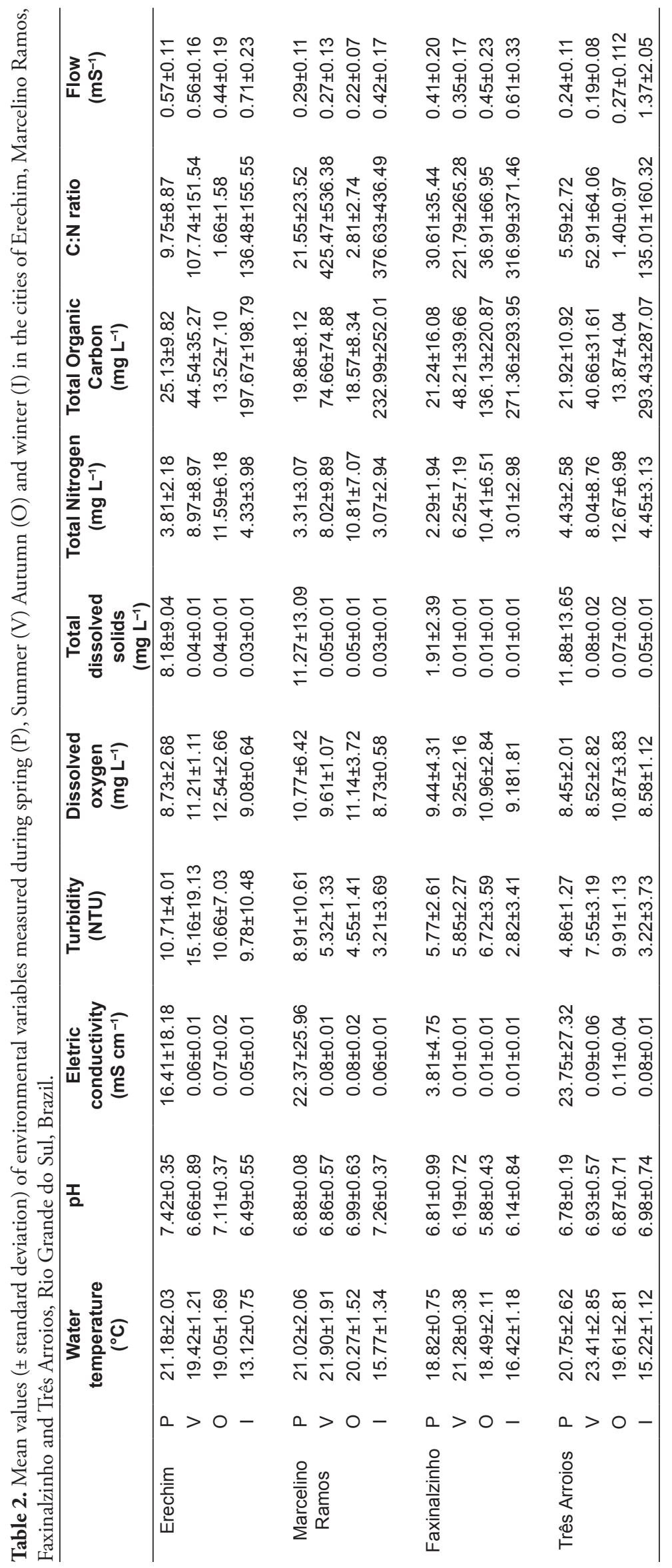




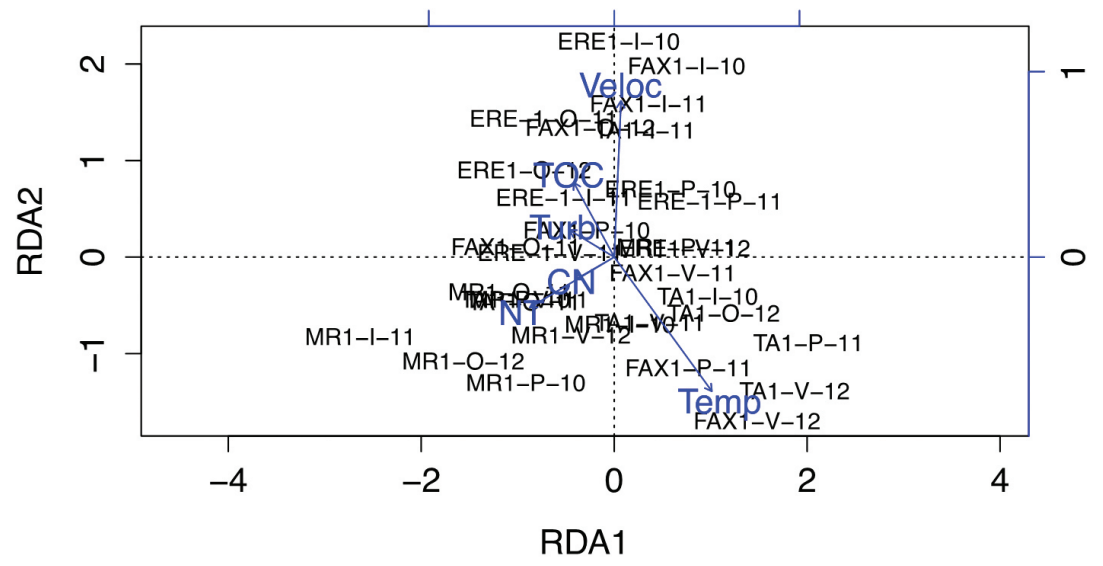

Figure 3. Redundance analysis with environmental variables and Chironomidae communities composition in the Alto Uruguai streams, Rio Grande do Sul, Brazil. ERE: Erechim; FAX: Faxinalzinho; TA: Três Arroios; MR: Marcelino Ramos; I: winter; V: summer; O: autumm; P: spring; 10, 11, 12: 2010, 2011, and 2012 years, respectivily. Veloc: current velocity; Turb: turbity; $\mathrm{CN}$ : carbon: nitrigen ratio; TOC: total organic carbon: TN: total nitrogen.

(Sensolo et al., 2012). Thus, in our study, TOC, $\mathrm{TN}$ and the C:N ratio variables might operate as environmental filters and thereby promote changes in the chironomid community, favoring dominant genera as Polypedilum e Rheotanytarsus. The streams located in Marcelino Ramos and Três Arroios showed a higher concentration of TOC.

The spatial distribution of chironomids is directly related to the environmental conditions of the sites, physical and chemical characteristics of streams define the water quality, and influence the distribution of this group (Fesl, 2002). Other studies have also identified variability in the chironomid community that is generated by spatial factors. Roque et al. (2010) found that physicchemical parameters of water and other factors such as substrate type and attributes of the landscape are important modulators of the chironomid community in subtropical streams. Tejerina and Malizia (2012) studied streams in Argentina and found variations in chironomids following an altitudinal gradient and in relation to environmental variables such as temperature, conductivity and $\mathrm{pH}$ gradient. A similar pattern to that in our study, was observed by Calle-Martínez and Casas (2006) and Milošević et al. (2012), who found a relationship between the Chironomidae community with variables indicative of eutrophication (e.g., nitrogen and phosphorus), emphasising the importance of water quality for community composition.

Temporal variability in the communities monitored was mainly related to water temperature. We observed a seasonal variation in the composition of the Chironomidae, where some genera were representative in summer (Thienemanniela, Pentaneura, Paratanytarsus, Parapentaneura, Parametriocnemus, Hudsonimyia, Labrundinea, and Larsia) and others in winter (Parakiefferiella, Paramerina, and Metriocnemus). These seasonal variations might be driven by climatic and hydrological factors that are altered in certain seasons (Tejerina and Malizia, 2012). Milošević et al. (2012) found many variations in the chironomid community in contrasting seasons such as summer and winter, because different weather conditions can promote the emergence of some species in particular. However, some studies have reported disturbances arising from hydrological variations in the chironomid community, especially in richness and abundance, where some species might disappear from the stream after heavy rainfall; others might decrease in abundance, whereas others persist.

These arguments highlight the importance of understanding the temporal and spatial distribution of chironomid communities, so that the natural variability of the community is considered in biomonitoring studies and leads to accurate results. Knowledge concerning the distribution of chironomids is an important ecological tool for biological studies; as well as being a prominent group in aquatic ecosystems, chironomids can represent indicators of the level of pollution in freshwater ecosystems in monitoring programmes.

\section{Acknowledgements}

RMR received financial support from CNPQ (proc.\#477274/2011-0 and proc.\#475251/2009-1) CB received scholarship fom Coordenação de Aperfeiçoamento de Pessoal de Nível Superior (CAPES). LUH received financial support from CNPq (proc.\#471572/2012-8) and FAPERGS (proc.\#12/1354-0). 


\section{References}

ABURAYA, FH. and CALLIL, C. 2007. Variação temporal de larvas de Chironomidae (Diptera) no Alto Rio Paraguai (Cáceres, Mato Grosso, Brasil). Revista Brasileira de Zoologia, vol. 24, no. 3, p. 565-572. http://dx.doi.org/10.1590/S010181752007000300007

ANJOS, AF., TAKEDA, AM. and PINHA, GD. 2011. Distribuição espacial e temporal das larvas de Chironomidae em diferentes ambientes do complexo - rio Baía, Estado do Mato Grosso do Sul, Brasil. Acta Scientiarum Biological Scienses, vol. 33, no. 4, p. 417-426.

American Public Health Association - APHA. 1998. Standard methods for the examination of water and wastewater. 20th ed. Washington.

ARMITAGE, PD., CRANSTON, PS. and PINDER, LCV. 1995. The Chironomidae: biology and ecology of non-biting midges. London: Chapman e Hall. $572 \mathrm{p}$.

BATTISTONI, D., HEPP, LU. and RESTELLO, RM. 2013. Fauna de Chironomidae (Insecta) em riachos de uma Unidade de Conservação no sul do Brasil. In SANTOS, JE. and ZANIN, EM., org. Faces da polissemia da paisagem: ecologia, planejamento e percepçáo. São Carlos: RiMA. p. 308-324. (vol. 5).

BERNARDI, S. and BUDKE, JC. 2010. Estrutura da sinúsia epifítica e efeito de borda em uma área de transiçáo entre floresta estacional semidecídua e floresta ombrófila mista. Floresta, vol. 40, no. 1, p. 81-82.

BIASI, C., TONIN, AM., RESTELLO, RM. and HEPP, LU. 2013. Colonisation of leaf litter by Chironomidae (Diptera): influence of chemical quality and exposure duration in a Neotropical stream. Limnologica, vol. 43, no. 6, p. 427-433. http://dx.doi.org/10.1016/j.limno.2013.01.006

BRODERSEN, KP. and ANDERSON, NJ. 2002. Distribution of chironomids (Diptera) in low arctic West Greenland lakes: trophic conditions, temperature and environmental reconstruction. Freshwater Biology, vol. 4, p. 1137-1157.

BUTZKE, A. 1997. Fitossociologia da vegetação do Alto Uruguai: seleção das espécies arbóreas para o reflorestamento dos municípios da regiáo. Leon: Universidad de Leon. [Tese de Doutorado]. PMid:9408990.

CALLE-MARTÍNEZ, D. and CASAS, JJ. 2006. Chironomid species, stream classification, and water-quality assessment: the case of 2 Iberian Mediterranean mountain regions. Journal of the North American Benthological Society, vol. 25, no. 2, p. 465-476. http://dx.doi.org/10.1899/08873593(2006)25[465:CSSCAW]2.0.CO;2

CHAIB, N., BOUHALA, Z., FOUZARI, L., MARZIALI, L., SAMRAQUI, B. and ROSSARO,
B. 2013. Environmental factors affecting the distribution of Chironomid larvae of the Seybouse wadi, North-Eastern Algeria. Journal of Limnology, vol. 72, no. 2, p. 203-214. http://dx.doi.org/10.4081/ jlimnol.2013.e16

DECIAN, VS., OLVEIRA, CH., ZANIN, EM., ROSSET, F. and FERRARI, CA. 2009. Uso da terra na região Alto Uruguai do Rio Grande do Sul e obtenção de banco de dados relacional de fragmentos de vegetação arbórea. Perspectiva, vol. 33, no. 121, p. 165-176.

DUFRÊNE, M. and LEGENDRE, P. 1997. Species assemblages and indicator species: the need for a flexible asymmetrical approach. Ecological Monographs, vol. 67, no. 3, p. 345-366.

ENTREKIN, SA., WALLACE, JB. and EGGERT, SL. 2007. The response of Chironomidae (Diptera) to a long-term exclusion of terrestrial organic matter. Hydrobiologia, vol. 575, no. 1, p. 401-413. http:// dx.doi.org/10.1007/s10750-006-0386-7

EPLER, J. 2001. Identification manual for the larval Chironomidae (Diptera) of North and South Carolina. Orlando: Departament of Enviromental and Natural Resources. 495 p.

FESL, C. 2002. Biodiversity and resource use of larvae chironomids in relation to environmental factors in a large river. Freswater Biology, vol. 47, no. 6, p. 1065-1087. http://dx.doi.org/10.1046/j.13652427.2002.00833.x

FERRINGTON, L. 2008. Global diversity of nonbiting midges (Chironomidae; Insecta-Diptera) in freshwater. Hydrobiologia, vol. 595, no. 1, p. 447455. http://dx.doi.org/10.1007/s10750-007-9130-1

GARCÍA, PE. and SUÁREZ, DAA. 2007. Community structure and phenology of chironomids (Insecta: Chironomidae) in a Patagonian Andean stream. Limnologica, vol. 37, no. 1, p. 109-117. http://dx.doi. org/10.1016/j.limno.2006.09.005

GONÇALVES JUNIOR, JF., ESTEVES, FA. and CALLISTO, M. 2003. Chironomids colonization on Nymphaea ampla L. detritus during a degradative ecological succession experiment in a Brazilian coastal lagoon. Acta Limnologica Brasiliensia, vol. 15, no. 2, p. 21-27.

GRESENS, SE., BELT, KT., TANG, JA., GWINN, DC. and BANKS, PA. 2007. Temporal and spatial responses of Chironomidae (Diptera) and other benthic invertebrates to urban stormwater runoff. Hydrobiologia, vol. 575, no. 1, p. 173-190. http:// dx.doi.org/10.1007/s10750-006-0366-y

HEPP, LU., MILESI SV., BIASI, C. and RESTELLO, RM. 2010. Effects of agricultural and urban impacts on macroinvertebrates assemblages in streams (Rio Grande do Sul, Brazil). Zoologia, vol. 27, no. 1, p. 106-113. http://dx.doi.org/10.1590/S198446702010000100016 
HEPP, LU., LANDEIRO, V. and MELO, AS. 2012. Experimental Assessment of the Effects of Environmental Factors and Longitudinal Position on Alpha and Beta Diversities of Aquatic Insects in a Neotropical Stream. International Review of Hydrobiology, vol. 97, no. 2, p. 157-167. http://dx.doi.org/10.1002/iroh.201111405

HEPP, LU. and MELO, AS. 2013. Dissimilarity of stream insect assemblages: effects of multiple scales and spatial distances. Hydrobiologia, vol. 703 , no. 1, p. 239-246. http://dx.doi.org/10.1007/s10750012-1367-7

KÖNIG, R. and SANTOS, S. 2013. Chironomidae (Insecta: Diptera) of different habitats and microhabitats of the Vacacaí-Mirim River microbasin, Southern Brazil. Anais da Academia Brasileira de Ciências, vol. 85, no. 3, p. 975-985. PMid:24068087. http://dx.doi.org/10.1590/S000137652013000300010

MACDONALD, EE. and TAYLOR, BR. 2006. Incidence of mentum deformities in midge larvae (Diptera: Chironomidae) from Northern Nova Scotia, Canada. Hydrobiologia, vol. 563, no. 1, p. 277-287. http://dx.doi.org/10.1007/s10750006-0012-8

MENDES, HF. and PINHO, LC. 2006. Chironomidae: situaçáo taxonômica atual. In Projeto Levantamento e biologia de Insecta e Oligochaeta aquáticos de sistemas lóticos do Estado de São Paulo. (Atualização setembro 2008). Available from: <http://sites.ffclrp.usp.br/ aguadoce/chironomidae/chiroindex.htm>.

MERRITT, RW., CUMMINS, RW. and BERG, MB. 2008. An introduction to the aquatic insects of North America. Dubuque: Kendal/Hunt. 1214 p.

MILOŠEVIĆ, D., SIMIĆ, V., STOJKOVIĆ, M., ĆERBA, D., MANČEV, D., PETROVIĆ, A. and PAUNOVIĆ, M. 2012. Spatio-temporal pattern of the Chironomidae community: toward the use of non-biting midges in bioassessment programs. Aquatic Ecology, vol. 47, no. 1, p. 37-55. http:// dx.doi.org/10.1007/s10452-012-9423-y

MORENO, JA. 1961. Clima do Rio Grande do Sul. Porto Alegre: Secretaria da Agricultura. 42 p.

OKSANEN, J., BLANCHET, FG., KINDT, R., LEGENDRE, P., O'HARA, RB., SIMPSON, GL., SOLYMOS, P., STEVENS, MH. and WAGNER, H. 2012. Multivariate analysis of ecological communities. In R-Forge. "vegan". Available from: $<$ http://vegan.r-forge.r-project.org/>.

OLIVEIRA-FILHO, AT., BUDKE, JC., JARENCOW, JA., EISENLOHR, PV. and NEVES, DRM. 2013. Delving into the variations in tree species composition and richness across South American subtropical Atlantic and Pampean forests. Journal of Plant Ecology, p. 1-23. In press.

PEETERS, E.; GYLSTRA, R. and VOS, JH. 2004. Benthic macroinvertebrate community structure in relation to food and environmental variables. Hydrobiologia, vol. 519, no. 1-3, p. 103-115. http://dx.doi. org/10.1023/B:HYDR.0000026497.48827.70

PINDER, LCV. 1986. Biology of Freshwater Chironomidae. Annual Reviews Entomology, vol. 31, p. 1-23.

R Foundation for Statistical Computing. 2010. R: a language and environment for statistical computing. Vienna. Available from: <http://www.R-project.org>.

RAUNIO, J., HEINO, J. and PAASIVIRTA, L. 2011 Non-biting midges in biodiversity conservation and environmental assessment: findings from boreal freshwater ecosystems. Ecological Indicators, vol. 11, no. 5, p. 1057-1064. http://dx.doi.org/10.1016/j. ecolind.2010.12.002

ROQUE, FO., CORBI, JJ. and TRIVINHOSTRIXINO, S. 2000. Consideraçóes sobre a utilização de larvas de Chironomidae (Díptera) na avaliação da qualidade da água de córregos do estado de São Paulo. In ESPÍNDOLA, ELG., BOTTAPASCHOAL, CMR., ROCHA, O., BOHER, MBC. and OLIVEIRA-NETO, AL., eds. Ecotoxicologia: perspectivas para o século XXI. São Carlos: RIMA, p. 564.

ROQUE, FO., SIQUEIRA, T., BINI, LM., RIBEIRO, MC., TAMBOSI, LR., CIOCHETI, G. and TRIVINHO-STRIXINO, S. 2010. Untangling associations between chironomid taxa in Neotropical streams using local and landscape filters. Freshwater Biology, vol. 55, no. 4, p. 847-865. http://dx.doi. org/10.1111/j.1365-2427.2009.02314.x

ROSIN, GC. and TAKEDA, AM. 2007. Larvas de Chironomidae arvas (Diptera) da planície de inundação do alto rio Paraná: distribuição e composiçáo em diferentes ambientes e períodos hidrológicos. Acta Scientarum Bioloy Sciense, vol. 29, no. 1, p. 57-67.

SENSOLO, D., HEPP, LU., DECIAN, V. and RESTELLO, RM. 2012. Influence of landscape on assemblages of Chironomidae in Neotropical streams. Annales de Limnologie - International Journal of Limnology, vol. 48, no. 4, p. 391-400. http://dx.doi. org/10.1051/limn/2012031

SERPA-FILHO, A., FERREIRA, RLM. and BARBOSA, UC. 2007. Ocorrência de Polypedilum (Tripodura) amataura Bidawid-Kafka, 1996 (Diptera; Chironomidae) em Aquascypha hydrophora (Berk.) Reid (Fungi; Stereaceae), com descrição da pupa na Amazônia Central, Brasil. Acta Amazonica, vol. 37, no. 1, p. 151-156. http://dx.doi.org/10.1590/S004459672007000100020

SILVA, MT., CALLI, CT., FANTIN-CRUS, I. and GIRARD, P. 2013. Factors structuring the spatial distribution of Chironomidae larvae community in the floodplain of the northern Pantanal, Brazil, Acta Limnologica Brasiliensia, vol. 25 no. 2, p. 131-139. http://dx.doi.org/10.1590/S2179975X2013000200004 
SILVER, P., WOOSTER, D. and PALMER, MA. 2004. Chironomid responses to spatially structured, dynamic, streambed landscapes. Journal of the North American Benthological Society, vol. 23, no. 1, p. 69-77. http://dx.doi.org/10.1899/08873593(2004)023<0069:CRTSSD>2.0.CO;2

TAKEDA, AM., FUJITA, DS. and FONTES JUNIOR, HM. 2004. Perspectives on exotic bivalves proliferation in the Upper Paraná River floodplain. In AGOSTINHO, AA., RODRIGUES, L. GOMES, L.C., THOMAZ, SM. and MIRANDA, LE., eds. Structure and functioning of the Paraná River and its floodplain. Maringá: EdUEM. p. 97-100.
TEJERINA, EG. and MALIZIA, NJ. 2012. Chironomidae (Diptera) larvae assemblages differ along an altitudinal gradient and temporal periods in a subtropical montane stream in Northwest Argentina. Hydrobiologia, vol. 686, no. 1, p. 41-54. http://dx.doi.org/10.1007/s10750-011-0984-x

TOKESHI, M. 1995. Species interactions and community structure. In ARMITAGE, PD., CRANSTON, PS. and PINDER, LCV., eds. The Chironomidae: biology and ecology of non-biting midges. London: Chapman \& Hall. 584 p.

Received: 20 January 2014 Accepted: 06 August 2014 